will continue the theoretical and elegant experimental work initiated under his leadership as the non-associated flow rule model is seen to be important in theoretical studies when the kinematics of a soil structure is being considered.

It is appropriate to mention that the concept of the non-coincidence of shearing planes (stress characteristics) and direction of particle movement (velocity field) is a fundamental concept of Rowe (1962) stress-dilatancy theory.

\title{
REFERENCES
}

Davis, E. H. (1968). Theories of plasticity and the failure of soil masses. In Soil mechanics-selected topics (ed. I. K. Lee). London: Butterworth.

HANSEn, BENt (1958). Line ruptures regarded as narrow rupture zones: basic equations based on kinematic considerations. Conf. Earth Pressure Probl., Brussels 1, 39-49.

JAmes, R. G. (1965). Stress and strain fields in sand. Ph.D. thesis, University of Cambridge.

LEE, I. K. \& Herington, J. (1970). A theoretical study of the pressures acting on a rigid wall by a sloping earth or rock fill. Research report R133, University of Sydney.

RoscoE, K. H. (1970). Tenth Rankine Lecture: The influence of strains in soil mechanics. Géotechnique 20, No. 2, 129-170.

Rowe, P. W. (1962). The stress dilatancy relation for static equilibrium of an assembly of particles in contact. Proc. $R$. Soc., series A 269, 500-527.

\section{SOME LOADING TESTS ON LONG PIPE PILES}

(McCammon, N. R. \& Golder, H. Q. (1970). Géotechnique 20, No. 2, 171-184; Discussion 20, No. 4, 459-460)

\section{R. A. Sullivan, McClelland Engineers, Inc., Houston, Texas}

The load test data presented by the Authors provide welcome information on the ultimate load capacity of relatively long low-displacement piles driven through loose granular soils and through moderately sensitive, stiff, overconsolidated clays. The installation procedures of the two test piles were similar to typical procedures currently used to drive long open-ended pipe piles for support of offshore platforms. The pile load test results and soil data thus offer an ideal opportunity for evaluating current design criteria suggested by McClelland et al. (1969) to predict the capacity of offshore piles by the static method.

Successful application of the static method depends upon selection of appropriate soil parameters to compute the unit skin friction $f$ developed along the shaft of a pile and the unit end bearing $q$ at the pile tip. The design value of $f$ and $q$ must reflect the final stress conditions in the soil around the pile and consequently are significantly influenced by initial soil conditions, pile type and size, and pile installation procedure. The suggested design parameters presented by McClelland et al. were developed for computing load capacity of heavily loaded, open-ended pipe piles driven into clay soils and into relatively dense granular soils.

\section{Test pile in granular soil}

The unit skin friction on a pile driven to a particular depth in sand is given by

$$
f=K p_{0} \tan \delta
$$

where $K$ is the coefficient of lateral earth pressure on the pile shaft, $p_{0}$ is the effective overburden pressure and $\tan \delta$ is the coefficient of friction between the pile and the sand. The coefficient of lateral earth pressure is a measure of the relative density of the sand surrounding the pile and the coefficient of friction is a measure of the texture of the sand.

From analyses of field observations on driven piles in sand Meyerhof (1951) concluded that the shaft friction coefficient $K$ tan $\delta$ for displacement type piles varies from about 0.25 in loose sand to about 1.0 in dense sand. McClelland et al. (1969) recommended a coefficient of lateral 
earth pressure $K$ of 0.7 for open-ended pipe piles driven into granular formations in a mediumdense to dense condition. Taking the coefficient of friction $\tan \delta$ to be 0.577 for clean sand; the shaft friction coefficient of a low-displacement pile in dense sand becomes approximately $0 \cdot 4$ : With the test pile driven to $149 \mathrm{ft}$ depth, the average skin friction between the steel pile shaft and the surrounding very loose to compact granular soil was $395 \mathrm{lb} / \mathrm{sq}$. ft. Taking the submerged unit weight of the loose granular soil to be $50 \mathrm{lb} / \mathrm{cu}$. $\mathrm{ft}$, the shaft friction coefficient was computed to be about $0 \cdot 1$. The load test results confirm that the shaft friction coefficient of a low-displacement open-ended pipe pile is about $40 \%$ of the value of a displacement-type pile driven into dense or loose granular soils. The criteria of McClelland et al. limit the unit skin friction to a maximum value of $1.0 \mathrm{ton} / \mathrm{sq}$. $\mathrm{ft}$ in dense clean sand and to lesser maximum values in silty sands and silts.

The unit end bearing of a pile is given by

$$
q=p_{0} N_{q}^{\prime}
$$

where $p_{0}$ is the effective overburden pressure and $N_{q}^{\prime}$ is the bearing capacity factor for a deep circular base. Based primarily on laboratory studies that have shown that sand grains will begin to crush at compressive stresses of 100-150 ton/sq. $\mathrm{ft}$, the criteria of McClelland et al. limit the unit end bearing in dense clean sand to $100 \mathrm{ton} / \mathrm{sq}$. ft. The tip of the test pile was embedded in dense fine sand having less than $10 \%$ by weight passing the no. 200 sieve. The load test results reveal that the unit end bearing of the test pile was $105 \mathrm{ton} / \mathrm{sq}$. $\mathrm{ft}$ tending to confirm the limitation imposed on the unit end bearing value by McClelland et al.

\section{Test pile in cohesive soil}

It is generally accepted that the adhesion mobilized at failure along the shaft of a pile driven into soft to firm clay (cohesive shear strength less than $1000 \mathrm{lb} / \mathrm{sq}$. $\mathrm{ft}$ ) is approximately equal to the shear strength of the clay. However, with piles driven into stiff to hard, overconsolidated clays (shear strength greater than $1000 \mathrm{lb} / \mathrm{sq}$. $\mathrm{ft}$ ) the adhesion mobilized is considerably less than the cohesive shear strength of the clay. McClelland et al. (1969) have suggested that the adhesion for steel pipe piles driven into stiff to very stiff, overconsolidated clays should be taken to be $1000 \mathrm{lb} / \mathrm{sq}$. ft or the expected shear strength for a normally consolidated clay (whichever value is greater) but the anticipated adhesion should also not be greater than the in situ cohesive shear strength. The friction load test conducted on the $100 \mathrm{ft}$ long pile yielded an average adhesion of $720 \mathrm{lb} / \mathrm{sq}$. $\mathrm{ft}$ which is less than $1000 \mathrm{lb} / \mathrm{sq}$. ft. However, the test pile was driven into an overconsolidated clay with a sensitivity between two and three that might be expected to develop less adhesion than an insensitive clay.

Much work has been done to correlate the adhesion determined from pile load tests with the measured shear strength of the clay. One method for relating the potential adhesion to the measured shear strength is by

$$
c_{\mathrm{a}}=\alpha c
$$

where $c_{\mathrm{a}}$ is the average adhesion along the embedded shaft, $c$ is the average cohesive shear strength and $\alpha$ is the adhesion coefficient that is less than unity. Most of the load tests analysed have been on piles less than $100 \mathrm{ft}$ long.

A compilation has been made of most of the published test load data on steel pipe piles that are accompanied by sufficient soil data to permit analysis of the test results. In Fig. 1 the adhesion coefficient is plotted against the average cohesive shear strength of the clay for steel pipe piles driven at eight different locations. The solid symbols are results from test piles driven into insensitive clays with a sensitivity of less than two and the open symbols represent overconsolidated clays of glacio-lacustrine origin with sensitivities between two and four. Peck (1954) reported the results of four load tests on 16 in. dia. pipe piles driven into stiff 


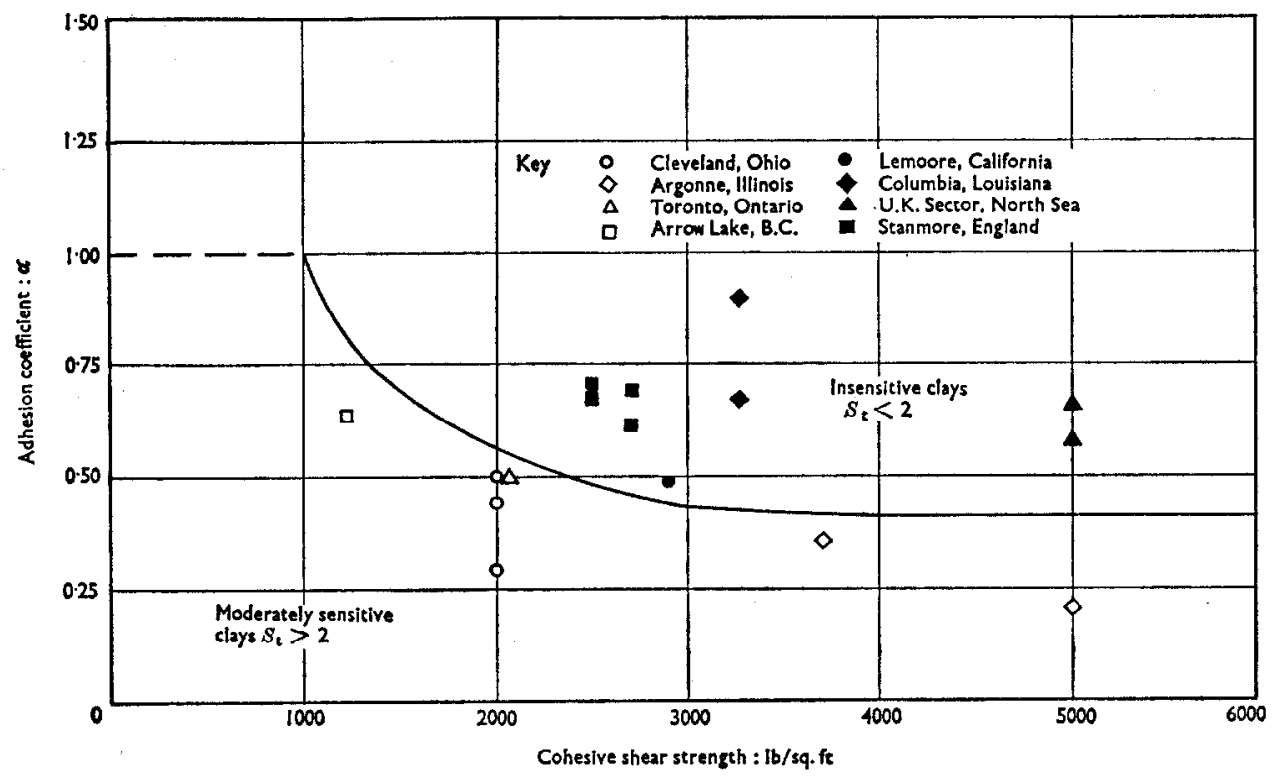

Fig. 1. Adhesion of steel pipe piles in stiff overconsolidated clays

lacustrine clay in Cleveland and later (Peck, 1958) presented load test results of two 10 in. pipe piles driven into very stiff clay of similar origin in Argonne in the Chicago area. Stermac et al. (1969) test loaded a 12 in. pipe pile installed in overconsolidated clay in the Toronto area. Of the load tests conducted by Woodward et al. (1961) in Pleistocene deposits in the Central Valley of California, only the load test result of the pile embedded entirely in stiff clay is plotted. Sherman (1969) reported the results of load tests on two 18 in. open-ended pipe piles that were instrumented to measure the load carried by stiff clay of Tertiary origin in the Mississippi alluvial valley. Fox et al. (1970) presented the results of load tests applied to an open-ended pipe pile driven to various penetrations into heavily overconsolidated North Sea Boulder and Lias clays. Results of load tests performed by Tomlinson (1971) on the four longer 6 in. pipe piles driven at Stanmore in London clay are plotted on Fig. 1.

The solid line shown on Fig. 1 separates adhesion coefficients for insensitive clays from coefficients for moderately sensitive clays. It is recognized that Fig. 1 has been developed from limited load test data but they provide a rational explanation to the wide scatter in adhesion coefficient values. Not unexpectedly, the proportional gain in shear strength of a relatively sensitive clay around a pile is smaller than the strength gain of an insensitive clay because of the disturbance of the flocculated structure and the breakdown of the cementation bonds in a sensitive clay. Without suggesting a design curve for either type of clay because of the limited data available, the plot of adhesion coefficient versus cohesive shear strength in Fig. 1 permits a range of coefficient values to be chosen with some degree of confidence for computing axial load capacity of steel pipe piles embedded as deep as $100 \mathrm{ft}$ in stiff overconsolidated clays.

\section{Comparison of computed and observed capacities}

By the static method, the ultimate capacity of a driven pile is computed by adding the end bearing at the pile tip to the numerical summation of the unit skin friction, or pileadhesion, down the length of the pile using an interpreted unit skin friction curve and the 


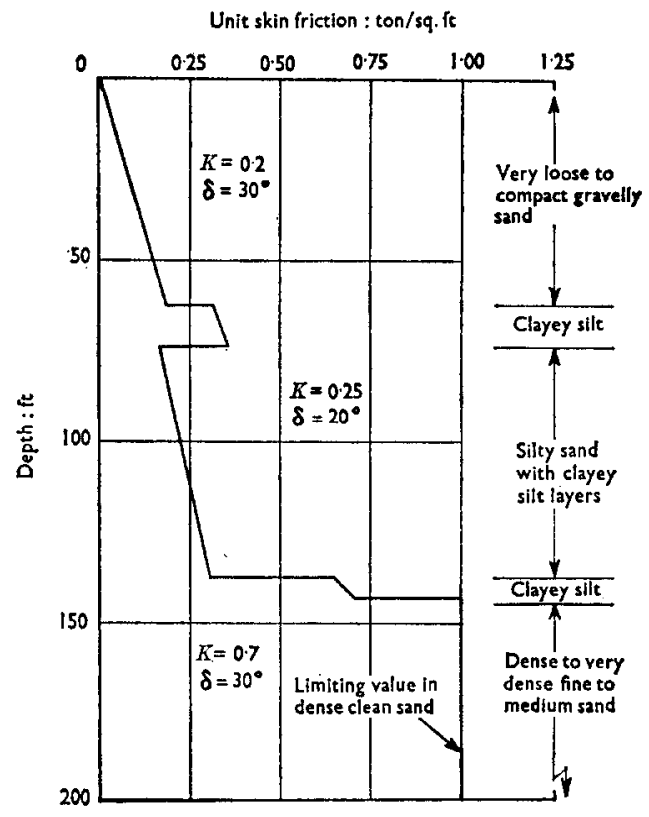

(a) Pile $I$ in sand

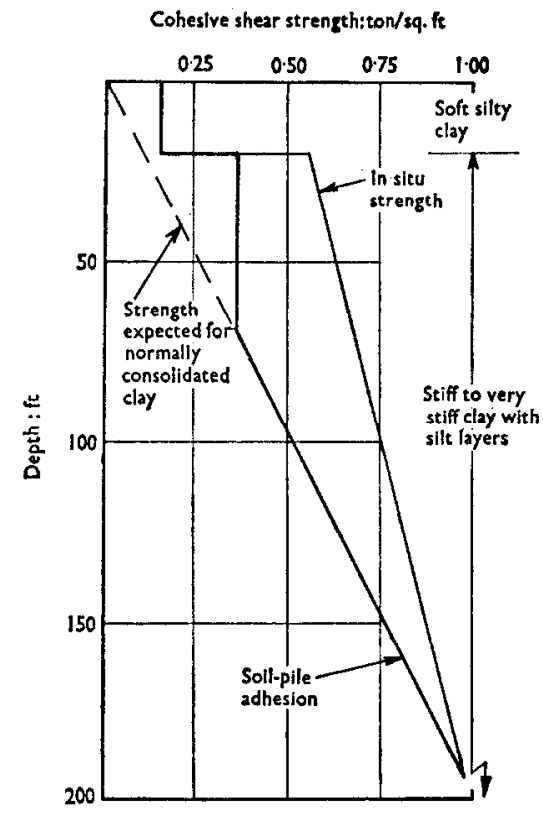

(b) Pile 2 in clay

Fig. 2. Unit skin friction curves

dimensions of the pile. The unit skin friction curve shown in Fig. 2(a) for the test pile in sand was developed using the selected soil parameters noted for each stratum with the submerged unit weight of the soil taken to be $50 \mathrm{lb} / \mathrm{cu}$. $\mathrm{ft}$. The coefficient of friction was selected based on the described textural characteristics of the soils and then the coefficient of lateral earth pressure was chosen so that the shaft friction coefficient was approximately 0.1 in the loose granular soils. Adhesion in the two clayey silt layers was taken to be equivalent to the shear strength expected for a normally consolidated clay with $c / p_{0}=0 \cdot 2$. The computed ultimate capacities for the test pile in granular soils are given in Table 1 with the unit end bearing in the dense sand limited to 100 ton/sq. $\mathrm{ft}$.

For the test pile in clay, the interpreted in situ shear strength profile and the interpreted soil-pile adhesion curve are shown in Fig. 2(b). The dashed curve indicates the shear strength that would be expected for a normally consolidated clay with $c / p_{0}=0 \cdot 2$. The soil-pile adhesion value in the stiff overconsolidated clay to $70 \mathrm{ft}$ depth was selected from the data presented in Fig. 1 and an adhesion coefficient of 0.5 was considered appropriate with the average shear strength of $1300 \mathrm{lb} / \mathrm{sq}$. ft for the moderately sensitive clay. The unit end bearing capacity was taken to be $c N_{c}^{\prime}$ where $c$ is the cohesive shear strength below the pile tip and $N_{c}^{\prime}$ has a value of 9 for a deeply embedded pile. Ultimate capacities given in Table 1 were computed using the heavy curve in Fig. 2(b) to represent the potential soil-pile adhesion.

In Table 1 the computed ultimate capacities by the static method are compared with the observed test loads. Using the design criteria suggested by McClelland et al. with slight modifications indicated by the present analysis of the load test data presented by the Authors, ultimate pile capacities are predicted within a range of about $10 \%$. It is generally accepted that computed and actual ultimate capacities of a pile may differ by $20 \%$ because of natural minor variations in subsurface materials and installation procedures from the conditions on which the computations were based. The predicted capacities are therefore within the range generally considered to be acceptable in design practice. 
Table 1. Comparison between computed and observed ultimate loads

\begin{tabular}{|c|c|c|c|c|c|c|}
\hline \multirow{3}{*}{ Soil type } & \multirow{3}{*}{$\begin{array}{c}\text { Pile } \\
\text { depth, ft }\end{array}$} & \multicolumn{3}{|c|}{ Computed load, tons } & \multirow{3}{*}{$\begin{array}{l}\text { Observed } \\
\text { load, tons }\end{array}$} & \multirow{3}{*}{$\frac{\text { Computed }}{\text { Observed }}$} \\
\hline & & \multirow{2}{*}{$\begin{array}{l}\text { Skin } \\
\text { friction, } Q_{\mathrm{s}}\end{array}$} & \multirow{2}{*}{$\begin{array}{l}\text { End } \\
\text { bearing, } Q_{\mathbf{p}}\end{array}$} & \multirow{2}{*}{$\begin{array}{c}\text { Ultimate } \\
\text { capacity, } Q\end{array}$} & & \\
\hline & & & & & & \\
\hline Sand & $\begin{array}{l}149 \\
155\end{array}$ & $\begin{array}{l}215 \\
215\end{array}$ & $\overline{314}$ & $\begin{array}{l}215 \\
529\end{array}$ & $\begin{array}{l}184 \\
515\end{array}$ & $\begin{array}{l}1 \cdot 17 \\
1 \cdot 03\end{array}$ \\
\hline Clay & $\begin{array}{l}100 \\
153\end{array}$ & $\begin{array}{l}209 \\
419\end{array}$ & $\overline{25}$ & $\begin{array}{l}209 \\
444\end{array}$ & $\begin{array}{l}226 \\
420\end{array}$ & $\begin{array}{l}0.93 \\
1.06\end{array}$ \\
\hline
\end{tabular}

The pile load test data indicate that two modifications should be made to the design criteria recommended by McClelland et al. (1969) for computing the capacity of open-ended pipe piles. First the shaft friction coefficient of a low-displacement pipe pile driven into loose granular soils should be taken to be $\mathbf{0 \cdot 1}$, and second soil-pile adhesion of steel pipe piles driven into moderately sensitive, stiff, overconsolidated clays should be anticipated to be smaller than the adhesion in insensitive clays. Fig. 1 may be used to aid selection of design adhesion values for steel pipe piles driven to depths of $100 \mathrm{ft}$ in overconsolidated clays.

\section{REFERENCES}

Fox, D. A., Parker, G. F. \& Sutton, V. J. R. (1970). Pile driving into North Sea boulder clays. Proc. 2na' offshove Technol. Conf., Houston 1, 535.

MCCIEILAND, B., FOCHT, J. A., Jr. \& EMrICH, W. J. (1969). Problems in design and installation of heavily loaded pipe piles. J. Soil Mech. Fdns Div. Am. Soc. civ. Engrs 95, SM6, 1491.

MEYerhoF, G. G. (1951). The ultimate bearing capacity of foundations. Géotechnique 2, No. 4, 301.

Peck, R. B. (1954). Foundation conditions in Cuyahoga River Valley. Proc. Am. Soc. civ. Engrs 80, Separate 513.

PECK, R. B. (1958). A study of the comparative behavior of friction piles. Highway Research Board, Special Report 36, National Research Council, Washington.

Sherman, W. C. (1969). Instrumented pile tests in a stiff clay. Proc. 7th Int. Conf. Soil Mech., Mexico 2, 227.

Stermac, A. G., Selby, K. G. \& Devata, M. (1969). Behavior of various types of piles in a stiff clay. Proc. 7th Int. Conf. Soil Mech., Mexico 2, 239.

Tominsson, M. J. (1971). Some effects of pile driving on skin friction. Conference on the behaviour of piles. London: Institution of Civil Engineers.

Woodward, R. J., Lundgren, R. \& Boitano, J. D. (1961). Pile loading tests in stiff clays. Proc. 5th Int. Conf. Soil Mech., Paris 2, 177.

\section{N. R. McCammon and H. Q. Golder}

In the Paper the Authors used a formula given by Meyerhof (1956) of $f_{\mathrm{s}}=N / 100$ to relate the skin friction on a pile in granular soil to the standard penetration number.

It has been suggested by Thorburn (1971) that the formula $f_{\mathrm{s}}=N / 50$ gives better agreement with the values measured in the test. This has been referred to Meyerhof (1971) who says, 'My relationship $f_{\mathrm{s}}=N / 50$ should have been used in your estimates for pipe piles. The value of $N / 100$ was derived for penetrometers and H-piles.'

The value of $N / 100$ was used deliberately since Meyerhof (1956) says that the ultimate bearing capacity of driven piles with small soil displacement (e.g. steel H-piles) may be taken as similar to that of a penetrometer with an average skin friction $f_{\mathrm{s}}=f_{\mathrm{c}}$.' This leads to the value $N / 100$.

Further Meyerhof explains the greater skin friction of piles as compared with penetrometers "by the greater lateral compression of the soil during installation of full-sized piles compared with that of a penetrometer.' 
The piles in the tests described in the Paper were driven open-ended and the material inside was cleaned out frequently. This was considered to be a non-displacement pile (p. 182). It might be argued that because the level of the soil dropped inside the pile during driving some plug action was occurring and some compaction of the surrounding soil took place. The important point is 'how much?' What does one assume in design? After many tests it would be possible to obtain a factor to apply to the Meyerhof formula to allow for the effect of the method of installation of the piles, which method would have to be carefully controlled. In the absence of such a figure to assume no compaction is playing safe.

The Authors would welcome other opinions on this point.

\section{REFERENCES}

Meyerhof, G. G. (1956). Penetration tests and bearing capacity of cohesionless soils. J. Soil Mech. Fdns Div. Am. Soc. civ. Engrs 82, SM1, January, 19 pp.

MeyerhoF, G. G. (1971). Private communication.

THorburn, S. (1971). Private communication.

\section{SHEAR STRENGTH OF MONTMORILLONITE}

(Mesri, G. \& Olson, R. E. (1970). Géotechnique 20, No. 3, 261-270)

\section{A. Sridharan and S. Narasimha Rao, Civil and Hydraulics Engineering Department, Indian Institute of Science}

The Authors have presented interesting data with regard to the shear strength of montmorillonite. It is interesting that the same failure envelopes were obtained by the Authors for undrained and drained tests. The experience of the Writers on similar types of calcium and sodium montmorillonite show a significant difference between the undrained and drained failure envelopes. Table 1 shows their index properties. Fig. 1 shows the failure envelopes for calcium montmorillonitc and Fig. 2 shows those for sodium montmorillonite.

The Writers have applied Bishop's (1954) energy correction to account for the work expended in the volume change during shearing. The difference between undrained and drained

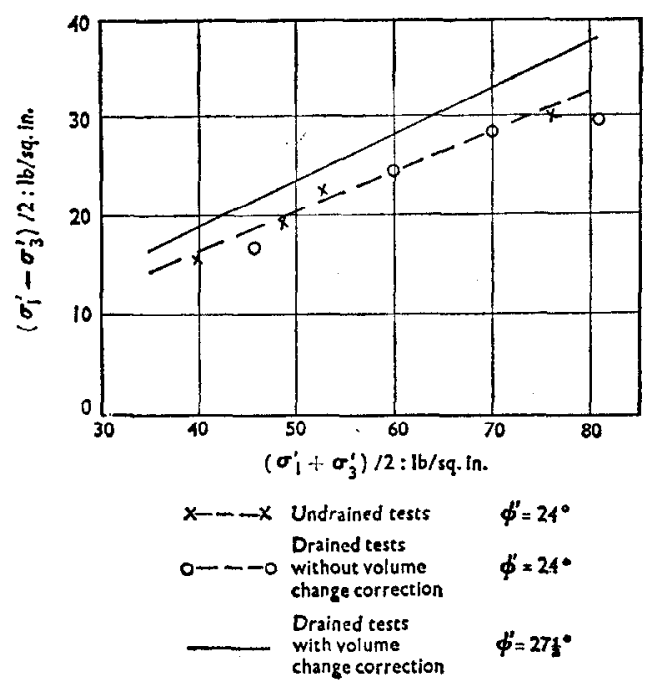

Fig. 1. Effective stress failure diagram for calcium montmorillonite

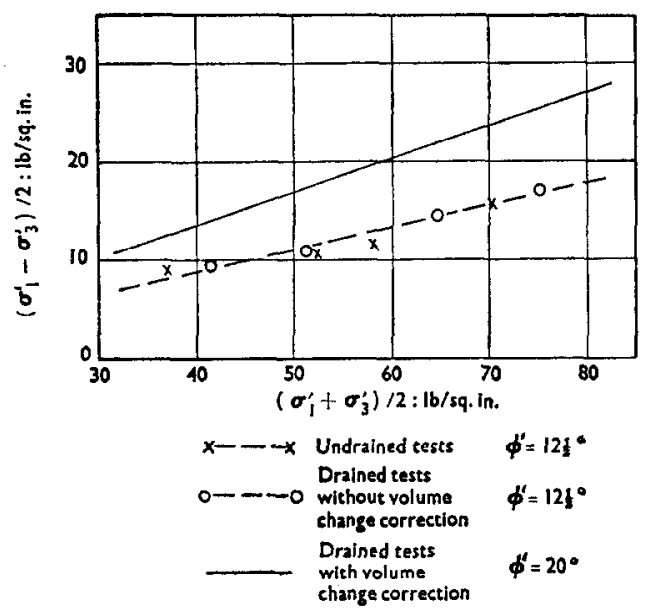

Fig. 2. Effective stress failure diagram for sodium montmorillonite 